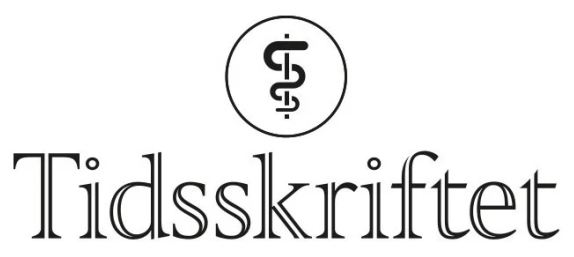

DEN NORSKE LEGEFORENING

\title{
Reinspikka om anatomien til sentralnervesystemet
}

ANMELDELSER

\section{VIDAR GUNDERSEN}

Overlege, Nevrologisk avdeling

Seksjon for bevegelsesforstyrrelser

Oslo universitetssykehus, Rikshospitalet

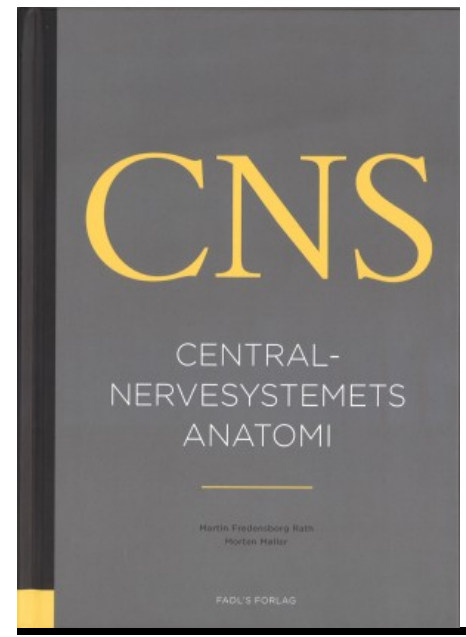

Martin Fredensborg Rath, Morten Møller

Centralnervesystemets anatomi

305 s, tab, ill. København: FADL's Forlag, 2020. Pris DKK 500

ISBN 978-87-93590-50-2

Centralnervesystemets anatomi er en lærebok i nevroanatomi. Målgruppene er medisin- og odontologistudenter.

Boka gir en oversiktlig innføring i feltet. Det er lett å finne fram i velavgrensede kapitler, som er rikt illustrert med bilder, tegninger og tabeller. Språket er dansk, men dette er ikke noe vesentlig problem for norske lesere. 
Boka gir en oversikt over oppbygningen til det sentrale nervesystemet: utvikling og de cellulære bestanddelene, deretter hinner og ventrikler, ryggmarg og hjernestamme og sensoriske og motoriske systemer, og til slutt det autonome nervesystemet, limbiske strukturer og hjernens blodforsyning. Forfatterne bruker gjennomført latinske betegnelser på strukturer. Hvert kapittel har et kortfatta resymé. Kapitlene avsluttes med spørsmål som tester om leseren har fått med seg hovedpoengene i teksten.

Som tittelen tilsier, gir boka nesten utelukkende en framstilling av sentralnervesystemets oppbygning og struktur. Forfatterne kommer kun med noen korte vurderinger av ulike hjerneområders funksjon, hovedsakelig markert som gult utheva bokser. Det samme gjelder kliniske eksempler, som er utheva med grønt. Jeg skulle gjerne sett at forfatterne i større grad integrerte struktur og funksjon og at de ga noen flere kliniske eksempler. Blant annet er funksjonen til limbiske strukturer lite omtalt. Forfatterne nevner at hippocampus er viktig for hukommelse, men de sier ingenting om betydningen for romlig orientering. Selvsagt må forfatterne ta hensyn til totalomfanget. Men dersom forfatterne hadde kosta på seg noen ekstra sider med funksjonelle betraktinger og klinisk relevant stoff, ville boka blitt mer fyldig og spennende å lese.

Hvorfor kjøpe denne boka når det finnes en mye bedre bok på norsk, nemlig Per Brodals Sentralnervesystemet? Rath og Møllers bok er inndelt som en blåkopi av Brodal sin, med de samme kapitlene, og en del av illustrasjonene ligner til forveksling. Min vurdering er at dette er en grei innføring i hjernens anatomi, men kunnskapen om sentralnervesystemet har fått en rivende utvikling de seinere åra, slik at struktur nå i større grad kan knyttes til funksjon. Etter min mening er det å kunne hoste opp anatomiske detaljer ikke noe mål i seg selv. Anatomien blir viktig først når den kan knyttes til normalfunksjon og patologi. I motsetning til Brodal klarer ikke Rath og Møller denne oppgaven.

Publisert: 28. september 2020. Tidsskr Nor Legeforen. DOI: 10.4045/tidsskr.20.0588

(C) Tidsskrift for Den norske legeforening 2023. Lastet ned fra tidsskriftet.no 26. april 2023. 